\title{
Climate Change and Sustainable Management of Salinity in Agriculture
}

\author{
Gurbachan Singh* \\ Ex-Chairman of Agricultural Scientists Recruitment Board, India
}

*Corresponding author: Gurbachan Singh, Beant Villa Building, Adjacent Adarsh Public School, Near Power House, Kunjpura Road, Karnal-132001, Haryana, India, Email: dr.gurbachan@gmail.com

Submission: 非 June 15, 2018; Published: 眥 August 09, 2018

\section{Introduction}

There has been a steady increase in the emission of greenhouse gases like carbon dioxide, methane and nitrous oxide in the environment. Agriculture is reported responsible for up to almost half of all methane emissions. The climate change predictions over India indicate that temperature rise is likely to be around 3 "C and rainfall increase is expected by 10-20 per cent over central states of India by 2100 A.D. The climate change triggered frequency of weather related events like floods, droughts, frost, cold and heat waves has considerably increased during last two decades. Continuation of such trends associated with rise in temperature is expected to melt ice, glaciers, re-distribute water flow in rivers, raise sea levels, sub-merge coastal habitats, islands, generate tsunamis and dislocate human and livestock settlements. Predicted spatial redistribution of precipitation, droughts, floods and water balance will change land use, pests, diseases and other ecological parameters. These changes will necessitate the need to devise research strategies to deal with predicted changes to sustain agricultural productivity and to achieve food and nutritional security in $21^{\text {st }}$ century.

Soil salinity and sodicity has degraded about 6.73 million ha otherwise productive area in the country. Development and refinement of appropriate technologies for reclamation and management of such lands seems promising option to achieve future food and nutritional security as well as adoption and mitigation strategy to cope with predicted future climate change scenario. In the present paper, information has been compiled and discussed how reclamation and management of salt - affected soils and waters will help sustaining food security and also help moderating/ negating climate change related risks in the near future through carbon sequestration in vegetation and soil. The information has been compiled under the sub heads: future climate change scenario in India, climate change and agriculture Vulnerability, impact of climate change on agriculture: recent case studies, harnessing saltaffected soils potential and future research and development needs.

\section{Future climate change scenario in India}

Table 1: Climate change projections for India.

\begin{tabular}{|c|c|c|c|c|c|}
\hline \multirow{2}{*}{ Year } & \multirow{2}{*}{$\begin{array}{c}\text { Sea- } \\
\text { son }\end{array}$} & \multicolumn{2}{|c|}{$\begin{array}{c}\text { Temperature Change } \\
\text { (OC) }\end{array}$} & \multicolumn{2}{c|}{ Rainfall Change (\%) } \\
\cline { 3 - 6 } & & & & & \\
\cline { 3 - 6 } & Lowest & Highest & Lowest & Highest \\
\hline & Annual & 1.00 & 1.41 & 2.16 & 5.97 \\
\hline 2020 s & Rabi & 1.08 & 1.54 & -1.95 & 4.36 \\
\hline & Kharif & $0 . B 7$ & 1.17 & $1 . B 1$ & 5.10 \\
\hline & Annual & 2.23 & 2.87 & 5.36 & 9.34 \\
\hline $2050 s$ & Rabi & 2.54 & 3.18 & -9.22 & 3.82 \\
\hline & Kharif & 1.81 & 2.37 & 7.18 & 10.52 \\
\hline & Annual & 3.53 & 5.55 & 7.48 & 9.90 \\
\hline $2080 s$ & Rabi & 4.14 & 6.31 & -24.83 & -4.50 \\
\hline & Kharif & 2.91 & 4.62 & 10.10 & 15.18 \\
\hline
\end{tabular}

Source: Lal [1]

The central research institute for dryland agriculture through its all India coordinated research projects on agro-meteorology and dryland agriculture has worked out the trends in maximum and minimum temperature during Kharif and Rabi season for Indian conditions. Their calculations indicate that there may be several location specific uncertainties in the minimum and maximum temperatures which may have adverse impact on agricultural production and productivity. Their calculations for trends in monthly rainfall in various sub-divisions in India indicate that rainfall may be more during December, January and February in case of West Rajasthan, Punjab and Haryana. However, there may be slight decrease in October and November rainfall in several divisions. The analysis was also made about trends of rainfall in India and shift in surplus rainfall for the period 1871 to 1999 and 1960 to 1999 . The observations indicate a shift in surplus rainfall from west towards east. Lal [1] made calculations about the 
predicted climate change and its impact on agriculture in India and the results are reported in Table 1 . He reported an annual mean area averaged surface warming over Indian Subcontinent to range between 3.5 to $5.5{ }^{\circ} \mathrm{C}$ over the region by 2080 . These projections showed more warming in winter season over summer monsoon. Rise in surface temperature in north India is predicted $3^{\circ} \mathrm{C}$ or more by 2050 . A marginal increase of 7 to $10 \%$ in rainfall is predicted over the subcontinent by 2080 . Further, the study revealed a fall in rainfall by 5 to $25 \%$ in winter months and an increase of 10 to $15 \%$ in summer monsoon rainfall in India. These projected changes will have both beneficial and adverse effects on agriculture, horticulture, environment and socio-economic set-up. To devise strategies to manage such changes and to reduce vulnerability of agriculture, careful analysis of old climate data and linking with weather forecasting and working out eco-years, eco-seasons, eco-months and eco-weeks at each agricultural university and ICAR research institute will be required. Samra and Singh (2002) suggested several strategies and contingent crop plans to negate/ moderate the impact of sub-dued rainfall/drought in different agrometeorological sub divisions of the country.

It has been estimated that mountain glaciers in the Himalayas and on the Tibet-Qinghai Plateau are melting and could deprive the major rivers of India and China of the ice melt needed to sustain them during the dry season in the future. Scientists believe that water flows in Yellow river and the Yangtze River basins where irrigated agriculture depends heavily on river will decrease and may have negative impact on food production. However, the scientists at the National Institute of Hydrology (NIH, Roorkee) have studied the glaciers in the Himalayas and their results indicate that situation is not that serious but there has been some decrease in the size of glaciers at some locations. There is a strong need to bench-mark the melting processes and their annual monitoring using GPS and satellite systems.

\section{Salinity problem: global and Indian scenario}

Soil and vegetation represent potential sinks for carbon sequestration and reforestation is considered as a possible means of mitigation of global warming. As per recent estimates nearly 953 million ha area is affected by salinity and sodicity in the world (Table 2). Australia followed by north and central Asia and south America have the maximum problem of high salt concentration in the root zone soil. State wise area affected by salinity and sodicity in India is given in Table 3. As per reconciled data reported in Table 3 , about 6.73 million ha otherwise productive area is constituted by salty lands. Gujarat state followed by UP has maximum area affected by salinity and sodicity. It has been further projected that 11.7 million ha area will be affected by 2025 .

Table 2: Distribution of salt affected soils in the world (million ha).

\begin{tabular}{|c|c|c|c|}
\hline Region & $\begin{array}{c}\text { Soionchaksl } \\
\text { Saline }\end{array}$ & $\begin{array}{c}\text { Solonetzl } \\
\text { Sodie }\end{array}$ & Total \\
\hline North America & 6 & 10 & 16 \\
\hline Mexico and Central America & 2 & - & 2 \\
\hline
\end{tabular}

\begin{tabular}{|c|c|c|c|}
\hline South America & 69 & 60 & 129 \\
\hline Africa & 54 & 27 & 81 \\
\hline South and West Asia & 83 & 2 & 85 \\
\hline South and East Asia & 20 & - & 20 \\
\hline North and Central Asia & 92 & 120 & 212 \\
\hline Australia & 17 & 340 & 357 \\
\hline Europe & - & - & 51 \\
\hline Total & - & - & 953 \\
\hline
\end{tabular}

Table 3: Extent of salt affected soils in India (ha).

\begin{tabular}{|c|c|c|c|}
\hline State & Saline & Sodic & Total \\
\hline Andhra Pradesh & 77598 & 196609 & 274207 \\
\hline Andaman \& Nicobar Island & 77000 & 0 & 77000 \\
\hline Bihar & 47301 & 105852 & 153153 \\
\hline Gujarat & 1680570 & 541430 & 2222000 \\
\hline Haryana & 49157 & 183399 & 232556 \\
\hline Karnataka & 1893 & 148136 & 150029 \\
\hline Kerala & 20000 & 0 & 20000 \\
\hline Madhya Pradesh & 0 & 139720 & 139720 \\
\hline Maharashtra & 184089 & 422670 & 606759 \\
\hline Orissa & 147138 & 0 & 147138 \\
\hline Punjab & 0 & 151717 & 151717 \\
\hline Rajasthan & 195571 & 179371 & 374942 \\
\hline Tamil Nadu & 13231 & 354784 & 368015 \\
\hline Uttar Pradesh & 21989 & 1346971 & 1368960 \\
\hline West Bengal & 441272 & 0 & 441272 \\
\hline Total & 2956809 & 3770659 & 6727468 \\
\hline
\end{tabular}

Table 4: Percentage use of poor quality waters in different states.

\begin{tabular}{|c|c|}
\hline State & Percentage (estimated values) \\
\hline Andhra Pradesh & 32 \\
\hline Gujarat & 30 \\
\hline Haryana & 62 \\
\hline Karnataka & 38 \\
\hline Madhya Pradesh & 25 \\
\hline Rajasthan & 84 \\
\hline Uttar Pradesh & 47 \\
\hline
\end{tabular}

\section{Source: CSSRI, Karnal}

Several studies in India [2] reveal that extremely carbon depleted soils like salt-affected soils have quite high potential for sequestering carbon in vegetation and soil if suitable tree and grass species are grown along with best management practices like rain water conservation. Nearly $25 \%$ of the ground water resources in India are saline and/or brackish. Continuous use of such water for irrigation is bound to increase soil salinity/sodicity. States like Rajasthan and Haryana have $84 \%$ and $62 \%$, respectively ground 
water as saline/sodie. Percentage use of poor quality waters in selected states is given in Table 4.

Introduction of irrigation in canal command areas coupled with over use of water has resulted in rise in ground water. In some of the canal commands water table is rising @ 0.3 to 1.2 meter/annum (Table 5). Nearly 3.55 million ha is already water logged and gone out of cultivation. Statewise extent of water logged area is reported in Table 6. Losses in productivity due to water logging are reported $42 \%$ in paddy, $38 \%$ in wheat, $77 \%$ in cotton and $61 \%$ in sugarcane compared to productivity of these crops in normal soils (Table 7).

Table 5: Rising trend of water table in irrigation commands.

\begin{tabular}{|c|c|}
\hline Irrigation Command & $\begin{array}{c}\text { Rise of Water Table (Meter/ } \\
\text { Annu) }\end{array}$ \\
\hline IGNp, Rajasthan & $0.29-0.88$ \\
\hline Western Yamuna and Bhakra canal & $0.30-1.00$ \\
\hline Sharda Sahayak, U.P. & 0.68 \\
\hline Nagarjuna Sagar, A.P. & 0.32 \\
\hline $\begin{array}{c}\text { Malprabha canal command, Karna- } \\
\text { taka }\end{array}$ & $0.60-1.20$ \\
\hline
\end{tabular}

Table 6: Extent of water logged areas in India.

\begin{tabular}{|c|c|}
\hline State & Waterlogged Area (mha) \\
\hline Andhra Pradesh & 0.43 \\
\hline Bihar & 0.35 \\
\hline Gujarat & 0.17 \\
\hline Haryana & 0.23 \\
\hline Karnataka & 0.05 \\
\hline Kerala & 0.08 \\
\hline Madhya Pradesh & 0.06 \\
\hline Maharashtra & 0.02 \\
\hline Orissa & 0.18 \\
\hline Punjab & 0.30 \\
\hline Rajasthan & 0.18 \\
\hline Tamil Nadu \& Pondicherry & 0.61 \\
\hline Uttar Pradesh & 0.59 \\
\hline West Bengal & 0.29 \\
\hline Total & 3.55 \\
\hline
\end{tabular}

Source: Ministry of Agriculture (Draft Report, 1999)

Table 7: Losses due to water logging and soli salinity.

\begin{tabular}{|c|c|c|c|}
\hline Crop & $\begin{array}{c}\text { Normal } \\
\text { Lands }\end{array}$ & $\begin{array}{c}\text { Salt Affected } \\
\text { Lands }\end{array}$ & Waterlogged Lands \\
\hline Paddy & 39.9 & $21.8(45)$ & $23.0(42)$ \\
\hline Wheat & 26.0 & $15.8(40)$ & $18.6(38)$ \\
\hline Cotton & 16.3 & $6.1(63)$ & $3.7(77)$ \\
\hline Sugarcane & 636.8 & $330.2(48)$ & $247.5(61)$ \\
\hline
\end{tabular}

\section{Reclamation and management strategies}

After the establishment of Central Soil Salinity Research Institute in 1969 at Kamal, several site-specific technologies have been developed for reclamation and management of saline and alkali soils. A gist of the relevant technological options is discussed as under: Sub-surface drainage technology has been developed to reclaim waterlogged saline soils. State-wise drained area covered is given in Table 8. Similarly, change in cropping intensity after installation of the drainage system is reported in Table 9.

Table 8: state wise drainage area covered.

\begin{tabular}{|c|c|c|}
\hline State & Irrigation Command & Area Covered (ha) \\
\hline \multirow[t]{2}{*}{ Rajasthan } & Chambal & 15,700 \\
\hline & Indira Gandhi Nahar Pariyojna & 500 \\
\hline \multirow{2}{*}{ Haryana } & Eastern Jamuna Canal & $1450+3000$ \\
\hline & Bhakhra Canal & $1300+1000$ \\
\hline Punjab & South West Punjab & $30+2000$ \\
\hline \multirow{3}{*}{ Karnataka } & Upper Krishna & 30 \\
\hline & Tungabhadra & 200 \\
\hline & Malparhba Ghatparbha & 20 \\
\hline \multirow{2}{*}{$\begin{array}{l}\text { Andhra } \\
\text { Pradesh }\end{array}$} & Nagarjuna Sagar & 50 \\
\hline & Krishna Western Delta & 50 \\
\hline $\begin{array}{l}\text { Madhya } \\
\text { Pradesh }\end{array}$ & Unspecified & 50 \\
\hline \multirow{2}{*}{ Maharashtra } & Uncommandedl Neera Canal & \multirow{2}{*}{$1000+1000$} \\
\hline & Command/others & \\
\hline \multirow{2}{*}{ Gujarat } & Mahi-Kadana & 150 \\
\hline & Ukai- Kakrapar & 80 \\
\hline Kerala & Acid Sulphate Soils & 30 \\
\hline Assam & Tea Gardens & 15 \\
\hline
\end{tabular}

Table 9: Change in cropping intensity.

\begin{tabular}{|c|c|c|c|}
\hline Place & $\begin{array}{c}\text { Before } \\
\text { Drainage }\end{array}$ & After Drainage & Increase (\%) \\
\hline Sampla & 0 & 200 & - \\
\hline Ismaila & 73 & 148 & 103 \\
\hline Gohana & 117 & 175 & 50 \\
\hline Konanaki & 70 & 90 & 29 \\
\hline Uppugunduru & 130 & 165 & 27 \\
\hline Islampur (Karnatka) & & & \\
\hline ORP & 0 & 200 & - \\
\hline Phase II & 88 & 156 & 77 \\
\hline
\end{tabular}

Several salt tolerant varieties of rice, wheat and mustard have been developed which can be grown either without or with half the recommended dose of amendments. The promising varieties are listed below:

Rice:

CSR 10, CSR 13, CSR 23, CSR 27, CSR 30 and CSR 36

Wheat: KRL 1-4, KRL 19, KRL210 and KRL213

\section{Mustard: $\quad$ CS 52, CS 54 and CS 56}

Besides these, salt tolerant trees, grasses, bushes, biofuel crops have been identified and agro-techniques for their successful 
In general, it is difficult to build organic carbon in soils where summer temperature exceeds $40-45^{\circ} \mathrm{C}$. However, integration of trees with crops in a unified agroforestry system helped building appreciable quantity of organic matter in the soil (Table 14).

Table 14: Change in soil properties $(0-30 \mathrm{~cm})$ under different tree-crop combinations in 5 years.

\begin{tabular}{|c|c|c|}
\hline Land use Systems & Organic Carbon (\%) & Available N (kg ha") \\
\hline Crop based system & +0.07 & +10 \\
\hline Eucalyptus based & +0.12 & +21 \\
\hline Acacia based & +0.20 & +31 \\
\hline Populus based & +0.17 & $+2 \mathrm{~S}$ \\
\hline
\end{tabular}

Role of trees having high transpiration rates has been exploited to lower the water table in areas where ground water is showing rising trends. This process is known as bio-drainage. Bio-drainage is defined as the process of removing the excess soil water through transpiration using bio-energy of the plant and radiation energy of the Sun. It is an option to prevent the development of water logged and saline soils especially in land locked areas where there is no possibility of disposing saline drainage effluent. Also, there are large areas which get water stagnation due to seepage from higher elevation, surface disposal of urban and industrial effluents and floods during rains, where due to their topographical locations, conventional system of de-watering through mechanical pumping and surface drainage is not possible. Promising tree species for biddrainage use include: Eucalyptus, jamun, shisham, bamboo, poplar etc.

\section{Salt affected grazing lands}

Salt affected grazing lands are predominant landscapes throughout the country. The biomass production capacity of these lands is relatively low because of poor soil health and management. The above ground biomass of saline communities in peripheral areas of runs in Rajasthan was reported ranging from 0.6 to O.S tha" while in saline depressions of Jaisalmer, some grass communities were found to produce from 0.30 to 0.65 t ha" forage biomass. Major species which contribute significant biomass as fodder in such lands include: Aeluropus, Atria/ex, Bothrioch/oa, Cenchrus, Chenopodium, Chloris, Cynodon, Dacty/octenium, Dichanthium, Eragrostis, LeptochJoa, Kochio, Ponicum, Sa/sola, Suaedo, Tribulus, Salvadora, Prosopis and Ziziphus. Similarly, the important top feed shrubs and trees include Ailanthus excelso, Acacia ni/otica, A. catechu, A/ eucophloea, A. tortilis, Balanites roxburghii, Prosopis cineraria, P.ju/ ifJora, Azadirachta indica, Albizia /ebbeck, Leucaena Jeucocephala, Dahlbergian sissoo, Melia ozadirach, Hordwickia binata, Grewia ovata, Ficus bengalensis, F. religiosa, Anogeissus pendula, Bauhinia variegata, B. racemosa, Butea monosperma, Cordia dichotoma, Flacourtia indica, Moringa o(eifera, Dichrostachys nuttiness, Morus alba, Ziziphus mauritiana and Z. nummularia. The leaves of most of these trees are rich in nutrients. This type of fodder becomes more relevant during drought scarcity period.

\section{Salt tolerant halophytic pastures}

Many halophytes grow in natural saline or other arid environments, which are rapidly deteriorating through the process of desertincation. It is necessary for plants growing under saline conditions to maintain a high concentration of osmotic substances to successfully overcome the water-relating forces of the surrounding soil. Halophytes growing in saline soil are able to change the osmotic potential of their cell sap whenever required.

The value of certain salt-tolerant shrub and grass species have been recognized by their incorporation in pasture-improvement programmes in many salt-affected dry regions throughout the world. There have been recent advances in selecting species with high biomass and protein levels in combination with their ability to survive a wide range of environmental conditions, including salinity and drought. Considerable success has been achieved in Indian Subcontinent and elsewhere in cultivating halophytic forages such as chenopads, especially Atriplex in areas subject to total summer drought on badly salt-affected lands. Grazing animals can meet their requirement of protein and metabolisable energy through mixture of salt land fodders, tops of plantations of halophytic shrubs/trees (providing crude protein) and a minimal understorey cover of forages. Another plant, which has attracted much attention as a fodder plant on soils affected by salinity and waterlogging is kallar grass (Leptochloa fusca). In India and Pakistan, this grass has been widely utilized for production in both alkali and saline waterlogged soils. In a silvi-pastoral system with trees such as Acacia nilotica, Prosopis job/iflora (the loppings of these could be used as forage) for initial four years. On an average Leptochloa could produce 15.6 to $17.4 \mathrm{t}$ ha-1 green forage per annum on highly alkaline soil $(\mathrm{pH}>10)$ even during low rainfall years. Species of halophytic forages like Sa/icomia, Chenopodium, Kochia, Atriplex, Salsa/a, 5uaeda, Trianthema, Portuleca, Tribulus and Alhogi along with several grasses such as Aeluropus/agopoides, Sporobo/us ( $S$. morginatus, S. airoides, S. diander, S. he/vo/us, s. tramu/us), Cynodon dactylions, Dactyloctenium sindicum, Pospalum vaginatum, Chloris gayana, Echinochloa turnerano, E. c\%num, Eragrostis ton ella, Dichanthium onnulatum, Brachiaria mutica, Bathriochloa pertusa and many others are commonly found grown naturally in both alkali and saline soils and contribute as forage even during drought period.

In many coastal areas (including low rainfall areas of United Arab Emirates and Rann of Kutchh in India) where mangroves occur sporadically and there is scarcity of fodder, the foliage of many mangroves and associated plants such as species of Pongamia, Barringtonia and many others, are used as forage for cattle, goats and camel. Among other trees particularly grown on inland salty lands, species of Acacia, Prosopis, Sa/vodora, Cordia, Ailanthus, Balanites and Ziziphus are traditional fodder plants of drought prone arid regions. Many species of Acacia (A. cyclopes, bivenosa, implies, halosericea, saligna, sa/icina, and victoria) and Prosopis (P. juliflora, cineraria, chilensis, giandu/osa, pa/lida and tamarugo) are among the most promising genetic resources to be utilized in developing fodder sources in drought prone areas. 


\section{Trees and bushes on field boundaries and bunds}

Painting of multipurpose tree species (MPTS) and promising bushes on the boundaries of agricultural fields in drought prone salt affected area is useful as (i) biefence protection against wild animals, (ii) as an alternate source of fodder, fuel and income generating products during severe drought, (iii) as vegetative barriers to conserve soil and water, (iv) moderating effects of drought through moderating micro-climate and (v) in some cases act as shelterbelts/wind breaks and carbon sequestration.

Farmers make high bunds on the periphery on their agricultural fields, plant Saccharum munja on top and fix thorny bushes/ branches of trees to protect their crops from wild animals. Such bio-fencing practices need replacements at shorter intervals and do not generate any product of economic value. The list of species which can be exploited as a live fence and drought moderating option includes: Capporis decidua, Opuntia ficu -indica, Leucaena leucocephala, Carrisa carandas, Lantana camara, Aloe Barbadians, Prosopis juliflora, etc.

\section{Underutilized agro forestry resources}

Large number of trees, bushes, shrubs and grasses are naturally growing as wild plants in rainfed regions of the world. Such plants are adapted to rainfed situations and have tremendous potential to be exploited as a food, forage, fuel and/or industrial crops [3,4]. Some of these plants are already exploited in different parts of the world. For example, edible cactus (Opuntia ficus indica) is being extensively used as a fruit, forage, vegetable and medicinal crop in countries like Mexico, Argentina, France, Brazil, Italy, South Africa and even in south western USA. The other uses of cacti in arid and semi-arid areas include: live fence, vegetative barrier for soil and water conservation in sloping land and as a wind break. A summary of Opuntia uses is presented in Table 13. The forage quality parameters of this underutilized plant as reported in literature are cited in Table 15.

Table 15: Range in values for cactus cladode composition for use in animal feed.

\begin{tabular}{|c|c|}
\hline Moisture content (\%) & $85-90$ \\
\hline Crude protein (\%) & $5-12$ \\
\hline In vitro dry matter digestibility (\%) & 75 \\
\hline In vitro protein digestivity (\%) & 72 \\
\hline Crude fibre (\%) & 43 \\
\hline $\mathrm{P}(0 / 0)$ & $0.08-0.018$ \\
\hline Ca (\%) & 4.2 \\
\hline $\mathrm{K}(\%)$ & 2.3 \\
\hline $\mathrm{Mg}(\%)$ & 1.4 \\
\hline Energy (Meal kg") & 2.6 \\
\hline Carotenoids (mg 100 g") & 29 \\
\hline
\end{tabular}

Similarly, trees of the genus Prosopis are highly tolerant to aridity and salts. Prosopis juliflora has the potential to grow greener even during severest drought period. The trees provide livelihood support in terms of firewood, fodder and even pods as human and cattle feed. It has also been exploited economically as timber, firewood and forage tree in countries like Brazil, Argentina, Peru, Mexico, Senegal, South Africa and USA [5-7]. Comparison of protein content of Prosopis julif/ora in relation to other important trees as reported in the literature is given in Table 16. The data indicates that the Prosopis pods and leaves contain almost similar protein as that found in alfalfa.

Table 16: Comparison of protein content of mesquite (Prosopis ju/iflora) products in relation to other products in Brazil.

\begin{tabular}{|c|c|}
\hline Product & Protein (\%) \\
\hline Pods (Prosopis julif/ora) & 12.9 \\
\hline Leaves (Prosopis juliflora) & 13.6 \\
\hline Maize (Zea mays) & 6 \\
\hline Alfalafa (Medicago sativa) & 14.1 \\
\hline Guinea grass (Panicum maximum) & 2.6 \\
\hline
\end{tabular}

To exploit the use of under - utilized plant resources as climate change adoption and mitigation strategy we need to focus on : (a) to prepare an inventory of under - utilized/un-exploited plants and maintain their germplasm for productivity and quality improvement, (b) identification of ecological limits and optimal management practices for promising species and their evaluation as mono-cultural mixed communities or even as under - storey crop with trees, and (c) linking research and developmental issues of under - utilized plants with already existing international networks on such plants and (d) standardization of post harvest processing techniques for value addition and marketing opportunities.

\section{Shelter belt}

Well-designed shelterbelts conserve moisture and soil against wind erosion, neutralize heat wave, cold wave and fruit fall due to wind blowing. In addition to these effects, shelterbelts can also provide a wide range of useful products, from poles and fuelwood to fruits, fodder, fibre and mulch. They have been planted quite extensively along Indira Gandhi Rajasthan Canal, roads, railway lines and around the orchards. Species of Eucalyptus, Populus, Cosuarina, Prosopis, Acacia, Leucaena, Azadirachta, Moringa and Gliricidia are most frequently grown as wind breaks/shelterbelts. These are distinguished from boundary plantations and living fences by their orientation, which must face the wind. Diversifying the species in the shelterbelt can also bring a wider variety of useful products to local users.

\section{Conclusion}

Development and refinement of technologies for rehabilitation of 120 million ha degraded/wastelands in general and about 7 million ha salt-affected soils in particular need to be considered on high priority. These carbon depleted soils will provide much needed opportunity to sequester carbon in the soil. Sequestration of carbon will not only imply increasing the amount of carbon entering the soil but also a decline in the amount leaving through rapid decomposition due to high temperature. Several studies 
in salt-affected soils proved that reclamation of alkali soils with amendment like gypsum application, and of saline soils by drainage installations will help in restoration of vegetation cover and increase of soil organic carbon. Association of grasses like Leptochloa fusca with multipurpose trees like Prosopis juliflora and Acacia nilotica in a unified agroforestry system in highly sodic soils in 4 to 7 year rotations has yielded biomass of about $24 \mathrm{t} \mathrm{ha-}{ }^{-1}$. Our several experiments in different agro-eco regions further proved that carbon content in the soil continued to increase with age of plantation, type of tree and grass species and stocking rate.

Large scale plantation efforts on salt affected soils will be called up on wastelands using funding support from the climate change related projects of Govt. of India. This seems to one of the promising options to moderate global warming impact on agriculture in the near future. Large scale promotion of biofuel crops and multi-enter prize agriculture practices and rainwater harvesting and re-use will be called upon to moderate/mitigate climate change related risk in agriculture.

\section{References}

1. Lal M (2001) Future climate change: Implications for Indian summer monsoon and its variability. Current Science 81(9): 1196-1207.

2. Yadav JSP, Singh K (1970) Tolerance of certain forest species to various degrees of salinity and alkali. Indian Forester 96(8): 587-599.

3. Singh G (2003) General review of opuntias in India. Journal of the Professional association of the cactus, pp. 30-46.

4. Singh G, Felker P (1998) Cactus now world foods. Indian farming, pp. 26-31.

5. Gill HS, Abrol IP, Samra JS (1987) Forest ecology and management. 22: 57-69

6. Samra JS, Singh G (2002) Drought management strategies. Natural Resource Management Division, ICAR, New Delhi, India, p. 65.

7. Singh G, Abrol IP, Cheema SS (1988) Agroforestry on alkali soils: effect of planting methods and amendments on initial growth, biomass accumulation and chemical composition of mesquite (Prosopis juliflora). Agroforestry Systems 7(2):135-160. (c) (i) Creative Commons Attribution 4.0

For possible submissions Click Here

\section{Submit Article}

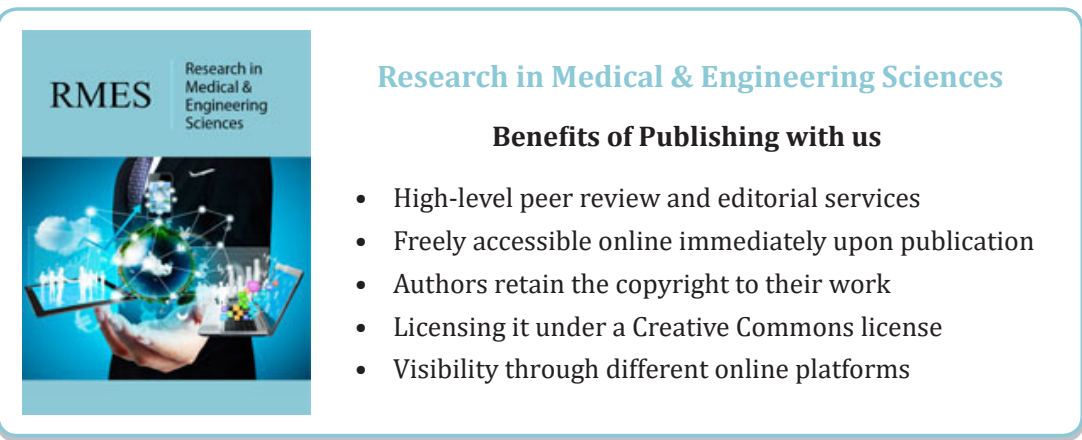

